Acta Theriologica $36(1-2): 47-62,1991$.

PL ISSN0001 - 7051

\title{
Allozyme variation and differentiation in Chionomys nivalis (Martins, 1842)
}

\author{
Maria Grazia FILIPPUCCI, Vittorio FADDA, Boris KRYŠTUFEK, \\ Shimon SIMSON and Giovanni AMORI
}

Filippucci M. G., Fadda V., Kryštufek B., Simson S. and Amori G. 1991. Allozyme variation and differentiation in Chionomys nivalis (Martins, 1842). Acta theriol. 36: 47 - 62.

Allozyme variation and divergence were investigated by electrophoretic analysis of 34 gene loci in eight populations of Chionomys nivalis from Northern Italy (Ch. n. nivalis, Ch. n. leucurus), Yugoslavia ( $C h . n$. malyi), and Israel ( $C h$. n. hermonis). The overall mean heterozygosity for all the populations sampled was $H=0.08$. A low mean value of genetic distance was found comparing Ch. n. nivalis and $C h$. n. leucurus $(D=0.02)$. Higher values of genetic distance were found comparing Italian and Yugoslavian populations $(D=0.08)$. The Israeli population from Mt. Hermon showed the highest values of genetic distance when compared with European populations $(D=0.16$, ranging from 0.129 to 0.215$)$ and four loci $(M e-1, M e-2,6 P g d h$, and $N p)$ were found discriminant and fixed for new alleles. The taxon hermonis could represent a separate species, but such hypothesis should be confirmed by further studies. Our results were also compared and combined, on the basis of 17 shared loci, with those obtained by Graf (1982) in populations from South Western Europe. Our data support Graf's hypothesis, according to which Western Alps were colonized by populations from South Western Europe, characterized by the allele $\delta 0$ at the locus Got-1, whereas Central Alps were colonized by eastern immigrants carrying the allele 100 for the locus Got-1.

Dipartimento di Biologia, II Università di Roma "Tor Vergata", Via O. Raimondo, 00173 Roma, Italy (MGF); Museo Civico di Storia Naturale di Milano, Corso Venezia 55, 20121 Milano, Italy (VF); Slovene Museum of Natural History, Prešernova 20, 61001 Ljubljana, Yugoslavia (BK); Institute of Evolution, Haifa University, Mt. Carmel, 31999 Haifa, Israel (SS); Centro di Genetica Evoluzionistica, C.N.R., Via Lancisi 29, 00161 Roma, Italy (GA)

Key words: allozyme variation, biochemical evolution, phylogenetic relationships, Chionomys nivalis

\section{Introduction}

The distribution of the Euro-Turanic species Chionomys nivalis (Martins, 1842) during the Würmian glaciation was widespread (Terzea 1972). At the end of that period the range of the snow vole was fragmented in small isolated populations (Farina and Cenni 1985), mainly linked to the mountain regions, between 1000 and $4700 \mathrm{~m}$ above the sea level. However, populations from Southern Europe (Spain, Southern France, Italy, Yugoslavia, Greece and Bulgaria) are also present at lower altitude $(100-600 \mathrm{~m}$ above the sea level; Krapp 1982). The snow vole is adapted to cavernicolous conditions inhabiting fissures typical of stony habitats. According to Kryštufek and Kovačić (1989), the preference of the snow vole for high mountain habitats in the Alps, Carpathians and Tatras is due to the lack of suitable cavernicolous conditions at lower altitude, especially below $1000 \mathrm{~m}$. Being mainly limited to the 
treeless mountain tops, the snow vole has a discontinuous distribution and it is considered as a glacial relict (Lanza and Azzaroli 1970). Such fragmentation led to the description of several subspecies (Spitzenberger 1971, Corbet 1978, Kratochvíl 1981, Krapp 1982); however, their status is not fully clarified.

The purpose of this study is to carry out a preliminar evaluation of allozyme variation and differentiation existing within and among European and Middle Eastern populations of Chionomys nivalis. A previous survey on genetic variation and differentiation among 24 species (8 genera) of the family Arvicolidae was carried out by Graf (1982) and based on 19-25 gene loci. Several populations of Chionomys nivalis from Spain, Switzerland, France and Central Italy were analyzed for 22 gene loci by this author. On the basis of the geographic distribution of the alleles scored at the locus Got-1, a double origin for the Alpine populations of the snow vole was hypothesized. According to Graf, at the end of Würm, the Western Alps were colonized by populations from south western refuges, whereas Central Alps populations originated from autochthonous populations or from eastern immigrants.

In the present paper, data are given on allozyme variation at 34 loci in several populations of the snow vole from Northern Italy (Ch. n. nivalis, Ch. n. leucurus), Yugoslavia (Ch. $n$. malyi), and Israel (Ch. n. hermonis). Our results are also compared and combined, on the basis of 17 shared loci, with those obtained by Graf (1982) for populations from South Western Europe (Ch. n. nivalis, Ch. n. leucurus, Ch. n. lebrunii, Ch. n. aquitanius) to verify his hypothesis concerning the origin of Alpine populations.

\section{Material and methods}

Electrophoretic analysis was carried out on 57 specimens representing 8 populations of Chionomys nivalis from Northern Italy, Yugoslavia and Israel. The number of specimens examined for each population, their collecting sites, taxonomic affiliation, and sample designations are given in Table 1; the distribution of sample localities is shown in Fig. 1. The animals, collected in 1985-1990 are deposited as standard museum preparations (skins and skulls) in the Slovene Museum of Natural History of Ljubljana and in the Museo Civico di Storia

Table 1. Taxonomic affiliation, collecting site, sample designation and number of specimens examined for each population of Ch. nivalis. See Fig. 1 for localities distribution.

\begin{tabular}{lllc}
\hline Subspecies & Collecting site & $\begin{array}{l}\text { Sample } \\
\text { Design. }\end{array}$ & N \\
\hline Ch.n. leucurus & Prati di Marta, Ligurian Alps, Italy & MAR & 2 \\
Ch. n. nivalis & St. Pierre, Valle d'Aosta, Italy & AOS & 20 \\
& Val Masino, Rethian Alps, Italy & MAS & 2 \\
Ch. n. malyi & Snežnik, Slovenia, Yugoslavia & SNE & 9 \\
& Mt. Šator, Bosnia, Yugoslavia & SAT & 1 \\
& Mt. Pelister, Macedonia, Yugoslavia & PEL & 13 \\
& Mt. Galičica, Macedonia, Yugoslavia & GAL & 2 \\
Ch.n. hermonis & Mt. Hermon, Israel & HER & 8 \\
\hline
\end{tabular}




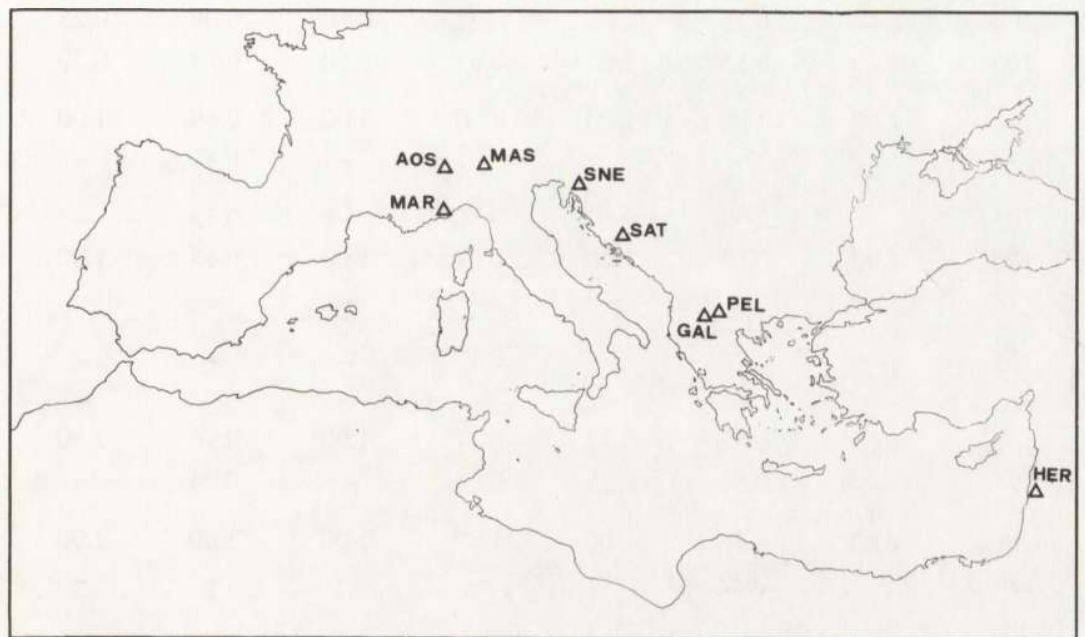

Fig. 1. Geographic distribution of the analyzed populations of Chionomys nivalis. See Table 1 for sample designations and localities.

Naturale of Milano. Tissues of each specimen were preserved in the laboratory at $-80^{\circ} \mathrm{C}$ until processed. Homogenates for electrophoresis were obtained from portions of muscle tissue crushed in distilled water.

Allelic variation at structural genes encoding for enzymatic proteins was assessed using standard horizontal starch-gel electrophoresis. All gels were prepared using an $11 \%$ suspension of Connaught hydrolyzed starch.

Homogenates obtained from muscle were processed for the following enzymatic proteins: $\alpha$-Glycerophosphate dehydrogenase (E.C. 1.1.1.8; $\alpha$-Gpdh), Sorbitol dehydrogenase (E.C. 1.1.1.14; $S d h$ ), Lactate dehydrogenase (E.C. 1.1.1.27; $L d h-1$ and $L d h-2$ ), Malate dehydrogenase (E.C. 1.1.1.37; $M d h-1$ and $M d h-2$ ), Malic enzyme (E.C. 1.1.1.40; $M e-1$ and $M e-2$ ), Isocitrate dehydrogenase (E.C. 1.1.1.42; $I d h-1$ and $I d h-2$ ), 6-Phosphogluconate dehydrogenase (E.C. 1.1.1.44; 6-Pgdh), Glucose-6-phosphate dehydrogenase (E.C. 1.1.1.49; $G 6 p d h$ ), Glyceraldehyde-3-phosphate dehydrogenase (E.C. 1.2.1.12; G3pdh), Indophenol oxidase (E.C. 1.15.1.1; $I p o$ ), Nucleoside phosphorilase (E.C. 2.4.2.1; $N$ p), Glutamate-oxalacetate transaminase (E.C. 2.6.2.1; Got-1 and Got-2), Hexokinase (E.C. 2.7.1.1; $H k-1$ and $H k$-2), Creatine kinase (E.C. 2.7.3.2; $C k$ ), Adenylate kinase (E.C. 2.7.4.3; Adk), Phosphoglucomutase (E.C. 2.5.7.1; Pgm-1 and Pgm-2), Esterases (E.C. 3.1.1.1; Est-1 and Est-3), Aminopeptidase (E.C. 3.4.11; Ap-1 and Ap-2), Leucyl aminopeptidase (E.C. 3.4.11; Lap), Acid phosphatase (E.C. 3.1.3.2; $A c p h$ ), Adenosine deaminase (E.C. 3.5.4.4; Ada), Aldolase (E.C. 4.1.2.13; Aldo), Fumarase (E.C. 4.2.1.2; Fum), Mannose phosphate isomerase (E.C. 5.3.1.8; Mpi), Glucose phosphate isomerase (E.C. 5.3.1.9; Gpi). 
Table 2. Allelic frequencies observed at 20 of the 34 loci analyzed in populations of $C h$. nivalis. For abbreviations of localities see Table 1 .

\begin{tabular}{|c|c|c|c|c|c|c|c|c|c|}
\hline Loci & Alleles & MAR & AOS & MAS & SNE & SAT & PEL & GAL & HER \\
\hline \multirow[t]{3}{*}{$\alpha-G p d h$} & 108 & - & - & - & 0.17 & - & 0.19 & 0.25 & - \\
\hline & 104 & - & 0.15 & - & 0.22 & 0.50 & 0.08 & 0.25 & - \\
\hline & 100 & 1.00 & 0.85 & 1.00 & 0.61 & 0.50 & 0.73 & 0.50 & 1.00 \\
\hline \multirow[t]{2}{*}{$S d h$} & 100 & 1.00 & 1.00 & 1.00 & 1.00 & 1.00 & 0.89 & 1.00 & 1.00 \\
\hline & 97 & - & - & - & - & - & 0.11 & - & - \\
\hline \multirow[t]{3}{*}{$M e-1$} & 105 & - & 0.37 & - & 0.39 & - & 0.35 & - & - \\
\hline & 100 & 1.00 & 0.63 & 1.00 & 0.61 & 1.00 & 0.65 & 1.00 & - \\
\hline & 97 & - & - & - & - & - & - & - & 1.00 \\
\hline \multirow[t]{4}{*}{$\mathrm{Me}-2$} & 105 & - & 0.12 & - & 0.17 & - & - & - & - \\
\hline & 103 & - & - & - & - & - & - & - & 1.00 \\
\hline & 100 & 1.00 & 0.82 & 0.75 & 0.77 & 1.00 & 0.96 & 1.00 & - \\
\hline & 95 & - & 0.06 & 0.25 & 0.06 & - & 0.04 & - & - \\
\hline \multirow[t]{2}{*}{$I d h-1$} & 100 & 1.00 & 0.78 & 1.00 & 1.00 & 1.00 & 1.00 & 1.00 & 1.00 \\
\hline & 80 & - & 0.22 & - & - & - & - & - & - \\
\hline \multirow[t]{3}{*}{ 6-Pgdh } & 106 & - & - & - & - & - & - & - & 1.00 \\
\hline & 103 & - & 0.08 & - & 0.11 & - & 0.19 & - & - \\
\hline & 100 & 1.00 & 0.92 & 1.00 & 0.89 & 1.00 & 0.81 & 1.00 & - \\
\hline \multirow[t]{3}{*}{ G3pdh } & 110 & - & - & - & - & - & 0.11 & - & - \\
\hline & 104 & - & 0.04 & - & 0.11 & - & 0.11 & 0.25 & - \\
\hline & 100 & 1.00 & 0.96 & 1.00 & 0.89 & 1.00 & 0.78 & 0.75 & 1.00 \\
\hline \multirow[t]{4}{*}{$N p$} & 112 & - & - & - & - & - & 1.00 & 1.00 & - \\
\hline & 108 & - & - & - & - & - & - & - & 1.00 \\
\hline & 104 & - & 0.22 & - & 0.11 & - & - & - & - \\
\hline & 100 & 1.00 & 0.78 & 1.00 & 0.89 & 1.00 & - & - & - \\
\hline \multirow[t]{4}{*}{ Got-1 } & 105 & - & 0.35 & 0.50 & 0.56 & 0.50 & 0.38 & - & 0.36 \\
\hline & 100 & - & 0.50 & 0.50 & 0.44 & 0.50 & 0.62 & 0.75 & 0.64 \\
\hline & 80 & 1.00 & 0.15 & - & - & - & - & - & - \\
\hline & 85 & - & - & - & - & - & - & 0.25 & - \\
\hline \multirow[t]{2}{*}{ Pgm-1 } & 103 & - & 0.23 & - & 0.22 & - & - & - & 0.08 \\
\hline & 100 & 1.00 & 0.77 & 1.00 & 0.78 & 1.00 & 1.00 & 1.00 & 0.92 \\
\hline \multirow[t]{3}{*}{$P g m-2$} & 105 & - & 0.10 & - & - & - & - & - & 0.19 \\
\hline & 100 & 1.00 & 0.90 & 1.00 & 0.94 & 1.00 & 1.00 & 1.00 & 0.81 \\
\hline & 95 & - & - & - & 0.06 & - & - & - & - \\
\hline \multirow[t]{3}{*}{ Est-1 } & 103 & - & 0.05 & - & - & - & - & - & - \\
\hline & 100 & 1.00 & 0.70 & 1.00 & 0.22 & - & 0.04 & 0.25 & 0.31 \\
\hline & 97 & - & 0.25 & - & 0.78 & 1.00 & 0.96 & 0.75 & 0.69 \\
\hline
\end{tabular}


Table 2 - continued

\begin{tabular}{|c|c|c|c|c|c|c|c|c|c|}
\hline Loci & Alleles & MAR & AOS & MAS & SNE & SAT & PEL & GAL & HER \\
\hline \multirow[t]{3}{*}{ Est-3 } & 105 & - & - & - & - & 1.00 & - & - & - \\
\hline & 100 & 1.00 & 0.95 & 1.00 & 0.94 & - & 0.96 & 1.00 & 1.00 \\
\hline & 96 & - & 0.05 & - & 0.06 & - & 0.04 & - & - \\
\hline \multirow[t]{2}{*}{ Acph } & 105 & - & 0.09 & - & 0.94 & 1.00 & 0.96 & - & 0.06 \\
\hline & 100 & 1.00 & 0.91 & 1.00 & 0.06 & - & 0.04 & 1.00 & 0.94 \\
\hline \multirow[t]{2}{*}{$A p-1$} & 105 & - & 0.35 & - & 0.17 & - & - & - & - \\
\hline & 100 & 1.00 & 0.65 & 1.00 & 0.83 & 1.00 & 1.00 & 1.00 & 1.00 \\
\hline \multirow[t]{3}{*}{$A p-2$} & 105 & - & 0.35 & - & 0.25 & 0.50 & - & - & 0.40 \\
\hline & 100 & 0.75 & 0.65 & 0.75 & 0.75 & 0.50 & 0.96 & 1.00 & 0.60 \\
\hline & 95 & 0.25 & - & 0.25 & - & - & 0.04 & - & - \\
\hline \multirow[t]{2}{*}{ Ada } & 106 & - & 0.20 & - & - & - & - & - & - \\
\hline & 100 & 1.00 & 0.80 & 1.00 & 1.00 & 1.00 & 1.00 & 1.00 & 1.00 \\
\hline \multirow[t]{2}{*}{ Aldo } & 105 & - & 0.05 & - & 0.11 & - & 0.20 & - & - \\
\hline & 100 & 1.00 & 095 & 1.00 & 0.89 & 1.00 & 0.80 & 1.00 & 1.00 \\
\hline \multirow[t]{3}{*}{$M p i$} & 105 & - & 0.10 & - & - & - & - & - & - \\
\hline & 100 & 1.00 & 0.90 & 1.00 & 1.00 & 1.00 & 0.96 & 1.00 & 1.00 \\
\hline & 95 & - & - & - & - & - & 0.04 & - & - \\
\hline \multirow[t]{2}{*}{$G p i$} & 105 & - & - & - & - & - & 0.11 & - & - \\
\hline & 100 & 1.00 & 1.00 & 1.00 & 1.00 & 1.00 & 0.89 & 1.00 & 1.00 \\
\hline
\end{tabular}

The following loci were monomorphic and fixed for the same allele in all the populations: $L d h-1, L d h-2, M d h-1$, Mdh-2, Idh-2, G6pdh, Ipo, Got-2, Hk-1,Hk-2,Ck, Adk, Lap and Fum.

The procedures were those described by Filippucci et al. (1988). Isozymes were numbered in order of decreasing mobility from the most anodal one. Allozymes were designated numerically according to their mobility, relative to the most common allele $(=100)(<100=$ slower mobility; $>100=$ faster mobility $)$ in the reference population AOS from Italy.

Allozymic data were analyzed as genotype frequencies with the BIOSYS-1 program of Swofford and Selander (1981). Intrapopulational genetic variation was estimated by the following indices: (1) mean heterozygosity per locus (observed, $\mathrm{Ho}$, and expected, $\mathrm{He}$; Nei 1978); (2) proportion of polymorphic loci in the population ( $P 1 \%$ - a locus is considered polymorphic if the frequency of the common allele does not exceed $0.99 ; P 5 \%$ if the frequency does not exceed 0.95); (3) mean number of alleles per locus (A). F-statistics (Wright 1978) were used to describe genetic differentiation among individuals within populations (individual inbreeding coefficient, $F_{\mathrm{IS}}$ ), among individuals within the species (overall individual inbreeding coefficient, $F_{\mathrm{IT}}$ ), and between population samples (fixation indices, $F_{\mathrm{ST}}$ ). A hierarchical analysis for comparisons of populations within and among subspecies was also performed (Wright 1978). In the hierarchical analysis, fixation indices were computed to estimate differentiation among subspecies and among populations within each subspecies.

The amount of genetic divergence between populations was estimated with the indices of genetic identity $(I)$ and distance $(D)$ proposed by Nei (1978). The high number of loci analyzed compensated for the small sample size of some populations. Values of heterozygosity and genetic distances are therefore reliable with a reasonable margin of precision (Nei 1978, Gorman and Renzi 1979, Sage et al. 1986). A dendrogram of the genetic relationships among populations was obtained using the unweighted pair group cluster analysis UPGMA (Sokal and Sneath 1963). 


\section{Results}

\section{Pattern of variation}

Fourteen of the thirty-four loci analyzed were monomorphic and fixed for the same allele in all the populations studied: $L d h-1, L d h-2, M d h-1, M d h-2, I d h-2, G 6 p d h, I p o, G o t-2, H k-1$, $H k-2, C k, A d k, L a p$, and Fum. The allele frequencies of the polymorphic and/or discriminant loci in the populations analyzed are given in Table 2.

In the Italian populations eighteen loci were found polymorphic: $\alpha-G p d h, M e-1, M e-2$, Idh-1, 6Pgdh, G3pdh, Np, Got-1, Pgm-1, Pgm-2, Est-1, Est-3, Ap-1, Ap-2, Acph, Ada, Aldo, and $M p i$. Eighteen loci were also found polymorphic in the Yugoslavian populations: $\alpha-G p d h$, Sdh, Me-1, Me-2, 6Pgdh, G3pdh, Np, Got-1, Pgm-1, Pgm-2, Est-1, Est-3, Ap-1, Ap-2, Acph, Aldo, Mpi, and Gpi. The specimens collected on the top of Mt. Hermon were polymorphic for six loci: Got-1, Pgm-1, Pgm-2, Est-1, Ap-2, and Acph.

\section{Genetic variation}

Levels of genetic variation within populations are shown in Table 3 . The overall mean heterozygosity $(\mathrm{He})$ for all the populations sampled was 0.08 and ranged from 0.01 (MAR) to 0.16 (AOS). According to Gorman and Renzi (1979), in populations with small sample size ( 1 - 2 specimens, as in MAR, MAS, SAT, and GAL) the heterozygosity could change by less than $2.5 \%$ as compared with a larger sample size. The overall mean proportion of polymorphic loci $(P 1 \%)$ for all the populations was 0.23 and ranged from 0.03 (MAR) to 0.53 (AOS). The overall mean number of alleles per locus $(A)$ was 1.26 , ranging from 1.03 (MAR) to 1.62 (AOS). The observed values of genetic variation are within the range generally reported for other rodents (Nevo et al. 1990). However, these values are higher than those observed in populations of Ch. nivalis from Central and Western Europe by Graf (1982). The mean value

Table 3. Levels of genetic variation, based on 34 loci, in populations of $\mathrm{Ch}$. nivalis (He: expected heterozygosity; $\mathrm{Ho}$ : observed heterozygosity; $\mathrm{A}$ : average number of alleles per locus; $P 1 \%$ and P5\%: proportion of polymorphic loci with $1 \%$ and $5 \%$ criterion).

\begin{tabular}{lccccc}
\hline Population & $H e$ & $H o$ & $A$ & $P 1 \%$ & $P 5 \%$ \\
\hline MAR* & 0.015 & 0.015 & 1.029 & 0.029 & 0.029 \\
AOS & 0.161 & 0.137 & 1.618 & 0.529 & 0.500 \\
MAS* & 0.049 & 0.059 & 1.088 & 0.088 & 0.088 \\
SNE & 0.136 & 0.139 & 1.500 & 0.441 & 0.417 \\
SAT* & 0.088 & 0.088 & 1.088 & 0.088 & 0.088 \\
PEL & 0.098 & 0.084 & 1.470 & 0.412 & 0.235 \\
GAL* & 0.069 & 0.059 & 1.147 & 0.118 & 0.118 \\
HER & 0.062 & 0.055 & 1.176 & 0.176 & 0.176 \\
Mean values & 0.085 & 0.079 & 1.264 & 0.235 & 0.206 \\
\hline
\end{tabular}

* Genetic estimates are tentative due to the small sample size. 
of heterozygosity observed by this author in 9 populations for 22 loci was $H=0.027$, ranging from 0 to 0.044 , whereas the mean value for six species of Microtinae was $H=0.043$. The lower values found by Graf (1982) could be attributed to the fact that enzymes as ME, NP, EST, and AP, codified by highly polymorphic loci, were not included in his analysis.

Table 4. Variable loci and Wright's (1978) non hierarchical $F$ - coefficients for $C h$. nivalis.

\begin{tabular}{lrrr}
\hline Locus & $F_{\mathrm{IS}}$ & $F_{\mathrm{IT}}$ & $F_{\mathrm{ST}}$ \\
\hline$\alpha G d p h$ & -0.047 & 0.174 & 0.211 \\
Sdh & -0.130 & -0.015 & 0.102 \\
Me-1 & 0.186 & 0.664 & 0.587 \\
Me-2 & -0.230 & 0.520 & 0.610 \\
Idh-1 & -0.004 & 0.200 & 0.203 \\
6Pgdh & 0.068 & 0.746 & 0.728 \\
G3pdh & -0.077 & 0.060 & 0.127 \\
Np & 0.136 & 0.898 & 0.882 \\
Got-1 & -0.367 & 0.068 & 0.318 \\
Pgm-1 & 0.014 & 0.161 & 0.149 \\
Pgm-2 & -0.164 & -0.038 & 0.108 \\
Ap-1 & -0.410 & -0.069 & 0.242 \\
Ap-2 & -0.244 & -0.011 & 0.187 \\
Ada & 0.375 & 0.487 & 0.179 \\
Mpi & -0.096 & -0.015 & 0.074 \\
Gpi & -0.130 & -0.015 & 0.102 \\
Aldo & 0.184 & 0.275 & 0.112 \\
Acph & -0.074 & 0.868 & 0.877 \\
Est-1 & 0.117 & 0.631 & 0.583 \\
Est-3 & 0.314 & 0.906 & 0.863 \\
Mean & -0.099 & 0.464 & 0.512 \\
\hline & & & \\
\hline
\end{tabular}

Table 5. Variance components and Wright's (1978) hierarchical $F$ - Statistics combined across loci in Ch. nivalis.

\begin{tabular}{|c|c|c|}
\hline Comparison & Variance & $F$ \\
\hline $\mathrm{X}$ & component & $\mathrm{XY}$ \\
\hline Population-subspecies & 1.528 & 0.361 \\
\hline Population - total & 2.338 & 0.464 \\
\hline Subspecies - total & 0.810 & 0.161 \\
\hline
\end{tabular}

Estimates of $F$-statistics for the twenty leading loci are given in Table 4 . The mean value observed for the individual inbreeding coeefficient was $F_{I S}=-0.099$, indicating a slight excess of heterozygosity within the populations. The mean value of the overall individual coefficient was $F_{\mathrm{IT}}=0.464$, indicating a deficiency of heterozygotes within the species. The mean value of the fixation index was $F_{\mathrm{ST}}=0.512$, indicating that $51 \%$ of genetic variation in the snow vole is due to differentiation existing among populations. The high mean value of the fixation index is indicating extensive genetic differentiation among the populations within the species. Hierarchical analysis (Table 5) pointed out that $16 \%$ of the differentiation is due to divergence among subspecies (0.161). Differentiation among populations within subspecies was higher (0.361).

\section{Genetic differentiation}

The specimens from Mt. Hermon can be differentiated from the European populations of $C h$. nivalis by four loci that displayed fixation of alternative alleles (Me-1, Me-2, $6 P g d h$, and $N p$ ). The locus Est-1 partially discriminates Israeli and Yugoslavian populations from the Italians. Moreover, Yugoslavian populations (excluding GAL) displayed a high frequency of the allele 105 for the locus Acph, that rarely appears in the Alps and Israel. The population from Ligurian Alps displayed fixation of the allele 80 at the locus Got-1, that is rare in Valle d'Aosta or absent in Val Masino, Yugoslavia, and Israel. 


\section{Genetic distance}

From the allele frequencies at the 34 loci tested, values of Nei's (1978) unbiased genetic identity $(I)$ and distance $(D)$ were calculated among populations for all pairwise comparisons (Table 6). An UPGMA dendrogram summarizing the genetic relationships found among the populations studied is given in Fig. 2. The observed values of genetic distances were low among Alpine populations. The value of genetic distance observed between the two populations of the taxon nivalis (MAS and AOS) was $D=0.013$. The mean value of genetic distance between the two taxa nivalis and leucurus was slightly higher: $D=0.025$. Higher values of genetic distance were found among Yugoslavian populations of $C h$. n. malyi, ranging from $D$ $=0.033$ (between GAL and PEL) to $D=0.110$ (between SAT and GAL). The mean value of genetic distance found comparing Alpine with Yugoslavian populations was $D=0.083$. The Yugoslavian populations showed lower mean value of genetic distance in comparisons with Ch. n. nivalis $(D=0.073)$, but $D=0.104$ when compared with $C h$. $n$. leucurus,

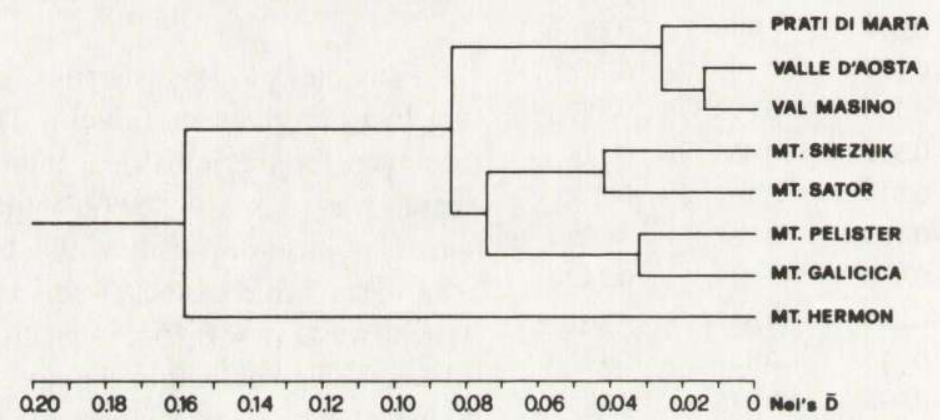

Fig. 2. UPGMA dendrogram summarizing the genetic relationships among the studied populations of Chionomys nivalis. $D=$ Nei's (1978) unbiased genetic distance, based on 34 enzyme loci. The cophenetic correlation coefficient is 0.86 .

Table 6. Values of Nei's (1978) unbiased genetic identity ( $I$; above the diagonal) and distance $(D$; below the diagonal) between populations of $\mathrm{Ch}$. nivalis from Italy, Yugoslavia, and Israel. For abbreviations of localities see Table 1 .

\begin{tabular}{lcccccccc}
\hline & MAR & AOS & MAS & SNE & SAT & PEL & GAL & HER \\
\hline MAR & & 0.967 & 0.984 & 0.921 & 0.875 & 0.881 & 0.929 & 0.839 \\
AOS & 0.034 & & 0.987 & 0.965 & 0.907 & 0.918 & 0.950 & 0.879 \\
MAS & 0.016 & 0.013 & & 0.948 & 0.898 & 0.905 & 0.949 & 0.870 \\
SNE & 0.082 & 0.036 & 0.054 & & 0.959 & 0.967 & 0.936 & 0.863 \\
SAT & 0.133 & 0.098 & 0.107 & 0.042 & & 0.920 & 0.896 & 0.807 \\
PEL & 0.127 & 0.086 & 0.100 & 0.034 & 0.084 & & 0.968 & 0.851 \\
GAL & 0.074 & 0.052 & 0.052 & 0.067 & 0.110 & 0.033 & & 0.868 \\
HER & 0.175 & 0.129 & 0.140 & 0.148 & 0.215 & 0.162 & 0.141 & \\
\hline
\end{tabular}


The mean genetic distance between the mountaintop population of Mt. Hermon and the other European populations was $D=0.16$, ranging from 0.129 to $0.215(D=0.17$ in comparisons with Ch. $n$. leucurus; $D=0.13$ in comparisons with Ch. n. nivalis; $D=0.17$ in comparisons with Ch. n. malyi).

Our results were also combined and compared with those obtained by Graf (1982). A tentative comparison was based on 17 shared loci, for which it was possible to assume homology between the alleles found by Graf and by us, and that codify for the following enzymes: $\alpha$-GPDH, SDH, LDH, MDH, IDH, 6PGDH, IPO, GOT, CK, ADK, PGM, LAP, and PGI. From the allele frequencies at the 17 shared loci, Nei's values of genetic identity and distance were calculated (Table 7). An UPGMA dendrogram summarising the genetic relationships found among the populations is given in Fig. 3.

The populations of Ch. n. nivalis from Valais Alps (ZER, FIO, BSP), Vaud Pre-Alps (PDN, JAM), Valle d'Aosta (AOS) and Val Masino (MAS) represent a homogeneous group $(D=$ 0.011 , ranging from 0.000 to 0.021 ). The Yugoslavian populations, attributed to the taxon malyi (according to Djulić and Mirić 1967) showed very low values of genetic distance $(D=$ 0.017 , ranging from 0.000 to 0.042 ) with respect to populations of the nominal subspecies,

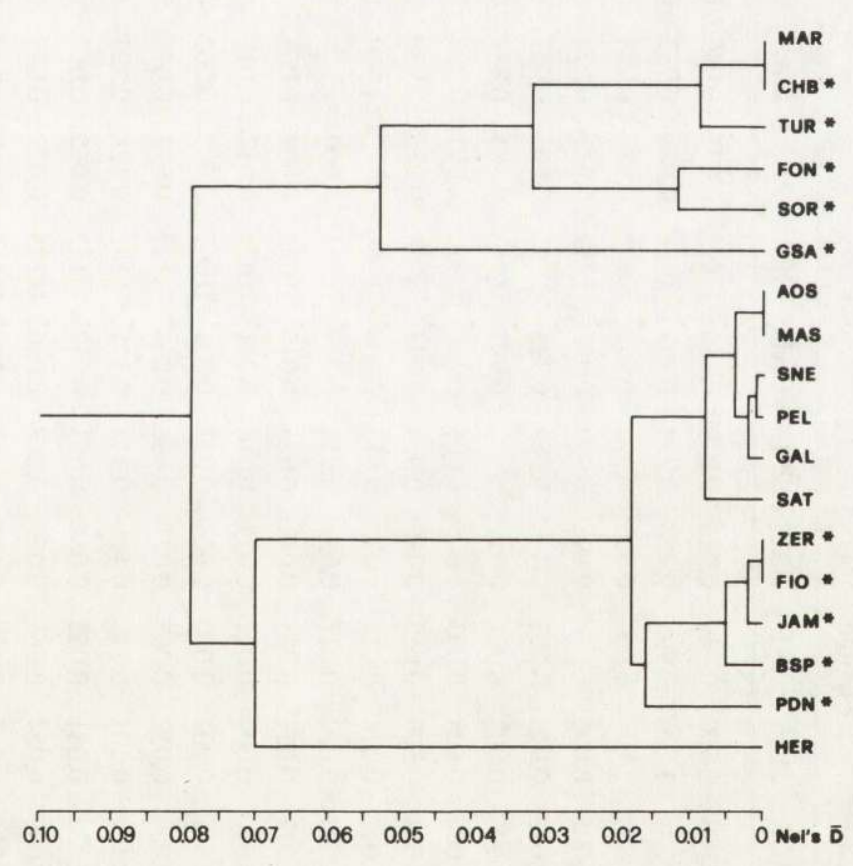

Fig. 3. UPGMA dendrogram summarizing the genetic relationships among European and Israeli populations of Chionomys nivalis. $D=$ Nei's (1978) unbiased genetic distance, based on 17 enzyme loci. The cophenetic correlation coefficient is $0.79 .{ }^{*}=$ data from Graf (1982): Ch. n. aquitanius: Sorpe, Spain (SOR); Font Romeu, France (FON). Ch. n. lebrunii: Chateaubourg, France (CHB). Ch. n. leucurus: Col de Turini, France (TUR); Ch. n. ssp: Gran Sasso, Italy (GSA). Ch. n. nivalis: Col de Jaman, Switzerland (JAM); Fionnay, Switzerland (FIO); Zermatt, Switzerland (ZER); Bourg St. Pierre, Switzerland (BSP); Pont de Nant, Switzerland (PDN). 


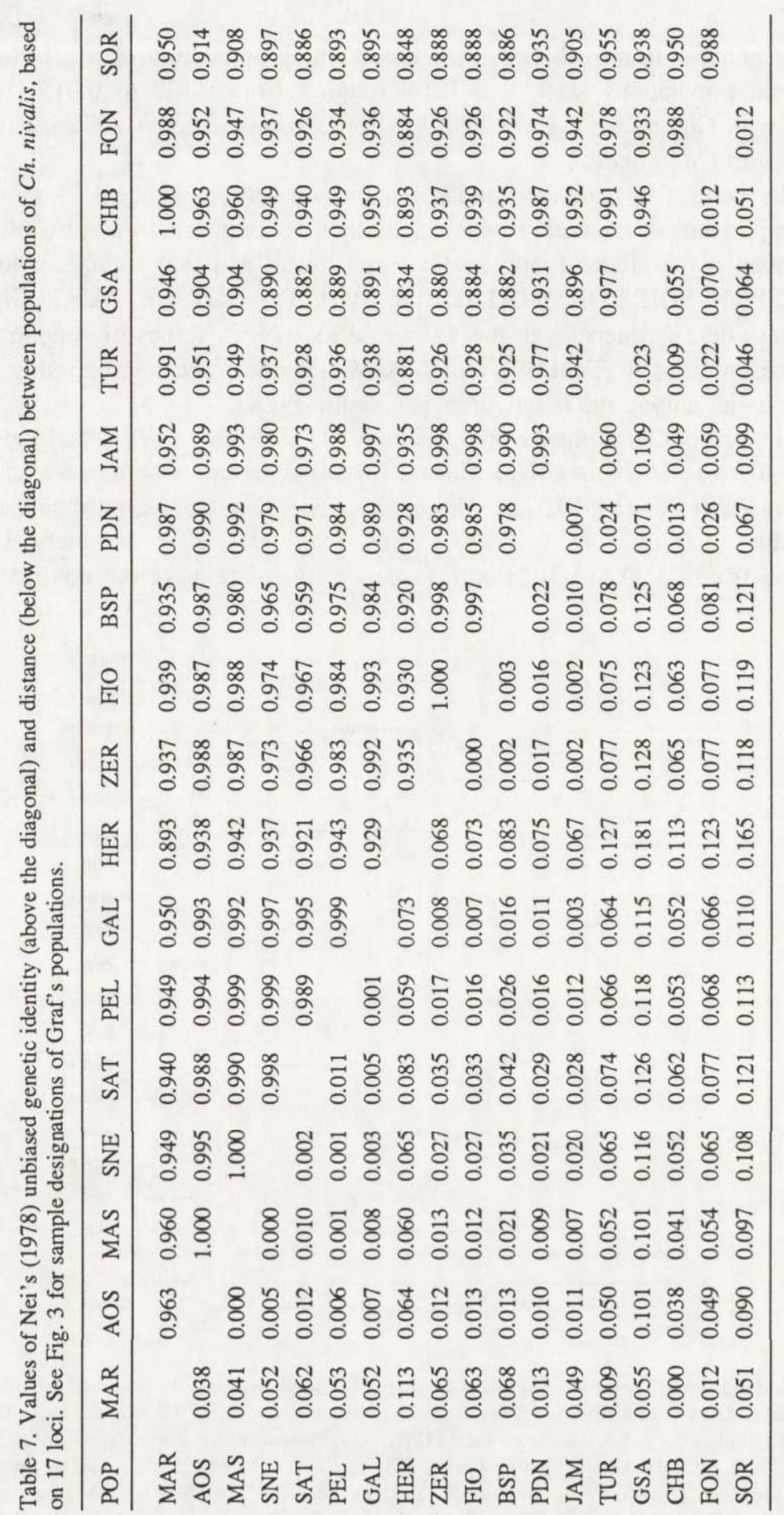


Table 8. Mean values of Nei's genetic distance observed at local populations and subspecies levels for several rodent species.

\begin{tabular}{|c|c|c|c|}
\hline Local population & $\begin{array}{l}\text { Nei's Genetic } \\
\text { Distance }\end{array}$ & $\begin{array}{c}\mathrm{N} \\
\text { loci }\end{array}$ & Reference \\
\hline Peromyscus boylii, P. pectoralis & $0.030(0.01-0.07)$ & 23 & Zimmermann et al. 1978 \\
\hline Arvicolidae (4 species) & $0.013(0.00-0.08)$ & $19-25$ & Graf 1982 \\
\hline $\begin{array}{l}\text { Apodemus sylvaticus, A. flavicollis, } \\
\text { A. mystacinus }\end{array}$ & $0.007(0.00-0.03)$ & 35 & Filippucci 1987, Filipucci et al. 1989 \\
\hline Eliomys quercinus, $E$. melanurus & $0.013(0.00-0.03)$ & 41 & Filippucci and Capanna 1991 \\
\hline Myoxus glis & $0.008(0.00-0.01)$ & 43 & Filippucci 1987 \\
\hline Dryomys nitedula & $0.032(0.01-0.04)$ & 40 & Filippucci 1987 \\
\hline Chionomys nivalis & $0.055(0.01-0.11)$ & 34 & Present study \\
\hline \multicolumn{4}{|l|}{ Subspecies } \\
\hline Peromyscus boylii, P. pectoralis & $0.052(0.04-0.06)$ & 23 & Zimmermann et al. 1978 \\
\hline Arvicolidae (4 species) & $0.064(0.01-0.18)$ & $19-25$ & Graf 1982 \\
\hline Apodemus sylvaticus, A. flavicollis & $0.066(0.00-0.12)$ & 35 & Filippucci 1987, Filippucci et al. 1989 \\
\hline Eliomys quercinus, E. melanurus & $0.064(0.03-0.13)$ & 41 & Filippucci and Capanna 1991 \\
\hline Myoxus glis & 0.063 & 43 & Filippucci 1987 \\
\hline Dryomys nitedula & $0.073(0.03-0.12)$ & 40 & Filippucci 1987 \\
\hline Muscardinus avellanarius & 0.086 & 37 & Filippucci 1987 \\
\hline Chionomys nivalis & $0.103(0.02-0.21)$ & 34 & Present study \\
\hline
\end{tabular}

when compared on the basis of 17 loci. The discrepancy between this value and that obtained on the basis of 34 loci $(D=0.073$, ranging from 0.036 to 0.107$)$ is due to the lack of two partially discriminant loci (Acph and Est-1) in the comparison with Graf's data. The group of populations belonging to the taxa nivalis and malyi showed relatively lower values of genetic distance ( $D=0.07$, ranging from 0.060 to 0.083 ) when compared with $C h . n$. hermonis, whereas $D=0.073$ (ranging from 0.013 to 0.128 ) in comparisons with leucurus, lebrunii, aquitanius, and the sample from Central Italy (Gran Sasso). The populations of the subspecies leucurus (Ligurian Alps, MAR, and Maritime Alps, TUR) and lebrunii (CHB) displayed very low values of genetic distance, $D=0.004$, whereas $D=0.033$ in comparison with aquitanius (FON and SOR).

The population from Gran Sasso (GSA) showed $D=0.053$, ranging from 0.023 to 0.070 , in comparison with the populations from Western Alps, Pyrenees, and Spain, whereas the mean values of genetic distance were higher in the comparisons with the populations attributed to nivalis $(D=0.108$, ranging from 0.071 to 0.128$)$, malyi $(D=0.119$, ranging from 0.115 to $0.126)$, and hermonis $(D=0.181)$.

Although three discriminant loci $(M e-1, M e-2$, and $N p)$ were not included in the analysis based on 17 loci, the Israeli population from Mt. Hermon still showed high values of genetic distance in comparison with those from Europe ( $D=0.094$, ranging from 0.06 to 0.18 ). 


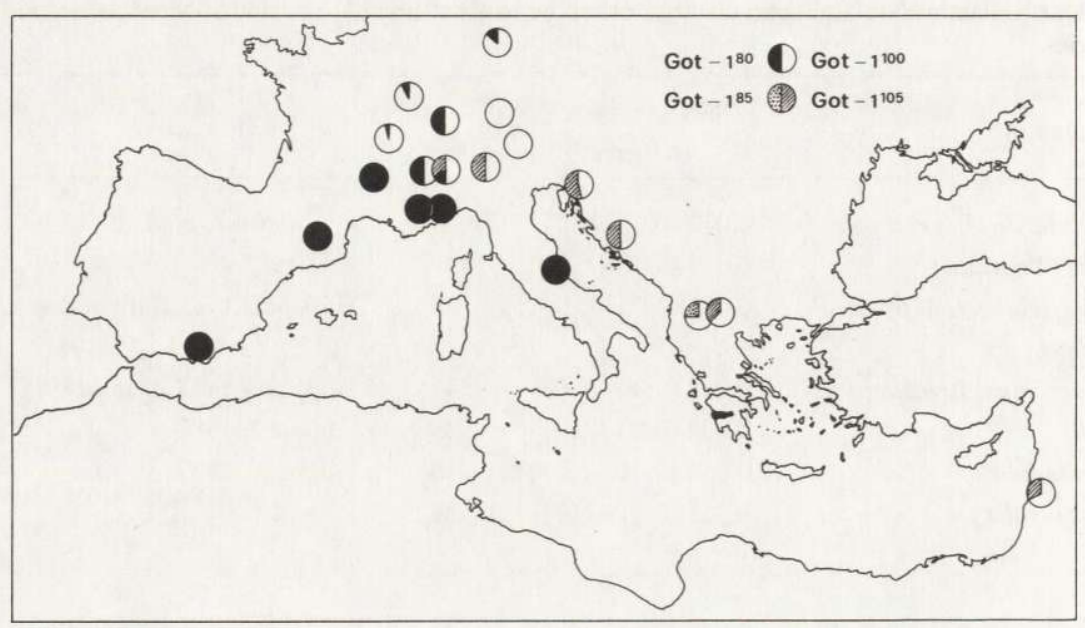

Fig. 4. Geographic distribution of the alleles $80,85,100$, and 105 observed at the locus Got-1 in European and Israeli populations of $C h$. nivalis. It includes the populations analyzed by Graf (1982).

\section{Discussion}

The discontinuities of distribution in Ch. nivalis and the consequent reduction or absence of gene flow among different isolates led to several geographical differences in allele frequencies, as shown in the European populations by the following loci: $\alpha-G p d h, S d h, I d h-1$, Np, Got-1, Pgm-2, Est-1, Est-3, Acph, Ada, Mpi, and Gpi. Moreover, the Israeli population displayed four discriminant loci $(M e-1, M e-2,6 P g d h$, and $N p)$. Geographical differences in allelic frequencies at several loci were also found by Graf (1982) among populations of Ch. nivalis from South Western Europe (Spain, Pyrenees, Maritime Alps and Central Italy) and Central Alps (France and Switzerland).

The effect of discontinuous distribution in reducing the gene flow is indicated by the high values of genetic distance observed among local populations $(D=0.055$, ranging from 0.013 to 0.110$)$ and subspecies $(D=0.103$, ranging from 0.016 to 0.215$)$ in the analysis based on 34 gene loci. The values of genetic distance observed among populations and subspecies in the snow vole are higher than those found in other rodent species (Table 8).

Extensive genetic differentiation among populations and subspecies within Ch. nivalis was also revealed by the high values observed at the fixation indices for the polymorphic loci $\left(F_{\mathrm{ST}}=0.512\right)$. The hierarchical analysis indicated only a $16 \%$ of the genetic variability was partitioned between subspecies, and differentiation was higher within subspecies (36\%). Estimates of the number of migrants exchanged between our population samples (Nm), calculated from $F_{\mathrm{ST}}=1 /(4 \mathrm{Nm}+1)$ (Wright 1943), also suggest a reduced gene flow: $\mathrm{Nm}=$ 0.238 , corresponding about to one migrant every four generations (Hartl 1988). 
Distinct differences among populations of $\mathrm{Ch}$. nivalis were also found by Nadachowski (1990) in tooth size and morphology. Such differences were related to the discontinuous geographical distribution of the snow vole and to different patterns of competitions in local communities.

The populations of $C h$. nivalis are relatively abundant in Central Alps, where they are found above $1500 \mathrm{~m}$, and the possibility of gene flow is provided by the high genetic homogeneity found between them. On the other hand, populations from South Western Europe are isolated (Graf 1982). The differentiation between populations from South Western and Central Europe ( $D=0.070$, based on 17 loci) is mainly due to the locus Got-1. Populations from South Western Europe (Spain, Pyrenees, Ligurian Alps, Maritime Alps, and Central Italy) can be discriminated by the allele 80 fixed for the locus $G$ ot-1. The same allele is rare in the transition area of Vaud Pre-Alps, Savoy Alps and Valle d'Aosta and absent in Valais (Switzerland), Val Masino (Italy), Yugoslavia and Israel. According to Graf (1982), at the end of Würm, Western Alps were colonized by populations from South Western European refuges, characterized by the allele 80 at the locus Got-1. The Central Alps populations instead originated from autochthonous populations or from eastern immigrants carrying the allele 100 for the locus Got-1. The hypothesis of Graf about eastern immigrants colonizing the Alps is supported by our data (Fig. 4), being the allele 100 of Got-1 present with a high frequency, together with the allele 105, in the populations from Val Masino, Yugoslavia and Israel, and absent in Ligurian Alps. The contact area between the two groups of populations is represented by Vaud Pre-Alps, Savoy Alps, and Valle d'Aosta, where both the alleles 80 and 100 of Got-1 are present.

Besides, the populations from South Western Europe displayed karyological differences when compared with those from Central Europe. According to Zima and Král (1984), who reviewed the literature on cytogenetic studies of $\mathrm{Ch}$. nivalis, the karyotype of the snow vole has been described from most of the mountain systems of Europe and it is characterized by a diploid chromosome number $2 n=54(\mathrm{NFa}=52)$; all the 26 pairs of autosomes are acrocentric. One of the smallest pair of autosomes was instead found submetacentric $(\mathrm{FNa}=54)$ by Meylan and Graf (1973) in Swiss Alps, France, and Sierra Nevada and by Jacenko (1982) in North West Caucasus.

The Yugoslavian populations, derived from four mountains of the Dinaric Alps and assigned to the taxon malyi by Djulić and Mirić (1967), displayed relatively great differences in morphological characters (Kryštufek 1990) and in allelic frequencies at several loci. The mean value of genetic distance observed among Yugoslavian populations was $D=0.062$, ranging from 0.033 to 0.110 . This value is relatively high and corresponds to that observed by Graf (1982) among subspecies in four species of Arvicolidae $(D=0.064$; see Table 8$)$. According to Kryštufek (1990) the subspecies category is inadequate to describe the complex geographic variations found in the snow vole populations from Yugoslavia, and Dinaric populations cannot be classified as a single subspecies because of relatively great differences among them. The analysis of colour, enamel tooth pattern, external features, and skull dimensions showed that not even two geographic samples are identical.

The Israeli population from Mt. Hermon showed the highest values of genetic distance when compared with European populations in both analyses: $D=0.09$, ranging from 0.06 to 
0.18 , based on 17 loci; $D=0.16$, ranging from 0.13 to 0.21 , based on 34 loci. The southern border of the distribution of Ch. nivalis is located on Mt. Hermon higher elevations (Tchernov and Yom-Tov 1988). The Hermon mountaintop population was described as a separate subspecies: Ch. n. hermonis Miller, 1908. This subspecies was also reported for Lebanon and Antilebanon mountains (Lewis et al. 1967, Spitzenberger 1971, Felten et al. 1973). Genetically, however, it showed low affinity with European populations of this species, having four loci fixed for new alleles never found in Europe $(M e-1, M e-2,6 P g d h, N p)$. The mean value of genetic distance observed in the comparison between European and Israeli populations ( $D=0.16$, ranging from 0.129 to 0.215$)$ is within the range generally observed among species of the same genus in mammals (Avise and Aquadro 1982) and, mainly, within the range observed among species of Arvicolidae ( $D=0.276$, ranging from 0.03 to 0.64; Graf 1982). Moreover, according to Thorpe (1982) and Nei (1987), if allopatric populations of dubious status have genetic identities below 0.85 and genetic distances higher than 0.16 , it is improbable that they are conspecific. Indeed, Mt. Hermon is at the southern continuation of the Antilebanon mountains, from which it is separated by a deep valley. The fauna and flora of this mountain (2814 m. a.s.l.) is a complex mixture of various zoogeographical elements, sorted along an altitudinal cline. Due to its position and high altitude, Mt. Hermon biogeographically represents an important southern outpost for many holoarctic species of plants and animals and a higher rate of speciation could be expected in its alpine tragacanthic belt. Numerous endemic species of plants and animals were described in this belt of Mt. Hermon and, more generally, in the Lebanon mountains (Shmida 1977, Werner and Avital 1980, Filippucci et al. 1989).

Therefore, the taxon hermonis could represent a separate species, but such hypothesis should be confirmed by further studies (such as biometric, karyotypic, and allozymic analyses) in which European taxa would be compared with those from Asia Minor and Middle East.

Acknowledgements: We are grateful to Dr. M. Cantini and to Dr. A. Tondina for their cooperations in providing specimens, to Mr. V. Salviati (A.T. CNR) for drawing the figures, and to Dr. O. Locasciulli who kindly read and revised the manuscript for English. We are also grateful to anonymous reviewers for providing constructive comments and suggestions on an earlier draft of this manuscript. This research was supported by grants from the Italian Ministry of Education (40\%): "Ricerche faunistiche nel Mediterraneo occidentale" and "Biologia Evolutiva dei Mammiferi".

\section{References}

Avise J. C. and Aquadro C. F. 1982. A comparative summary of genetic distances in the Vertebrates. [In: Evolutionary Biology. Hecht, Wallace, Prance, eds]. 15: 151 - 185.

Corbet G. B. 1978. The mammals of the Paleartic Region: a taxonomic revue. British Museum (Nat. Hist.), Cornell Univ. Press, London: $1-314$.

Djulić B. and Mirić D. 1967. Catalogus Faunae Jugoslaviae, IV/4 Mammalia. Cons. Acad. Sci. et Art. SFRY, Ljubljana: $1-46$.

Farina A. and Cenni M. 1985. The geographical distribution of the snow vole Chionomys nivalis (Mammalia, Rodentia) in the Northern Apennines. Boll. Mus. S. Nat. Lunig. 3: 27 - 31 .

Felten H., Spitzenberger F. and Storch G. 1973. Zur Kleinesäugerfauna West-Anatoliens. Teil II. Senckenbergiana biol. 54: $227-290$.

Filippucci M. G. 1987. Evoluzione cromosomica e genica in Micromammiferi dell'area mediterranea (Talpidae, Gliridae, Muridae). Ph.D. Thesis, University of Padova, Padova: $1-99$. 
Filippucci M. G. and Capanna E. 1991. Allozyme variation and differentiation among chromosomal races and species of the genus Eliomys (Rodentia, Gliridae). $1^{\text {st }}$ European Congress of Mammalogy, 18-23 March 1991, Lisboa, Portugal. Program and Abstracts: 123 - 124.

Filippucci M. G., Rodinò E., Nevo E. and Capanna E. 1988. Evolutionary genetics and systematics of the garden dormouse, Eliomys Wagner, 1840. 2 - Allozyme diversity and differentiation of chromosomal races. Boll. Zool. 55: $47-54$.

Filippucci M. G., Simson S. and Nevo E. 1989. Evolutionary biology of the genus Apodemus Kaup, 1829 in Israel. Allozymic and biometric analyses with description of a new species: Apodemus hermonensis (Rodentia, Muridae). Boll. Zool. 56: 361 - 376.

Gorman G. C. and Renzi J., Jr. 1979. Genetic distance and heterozygosity estimates in electrophoretic studies: effects of sample size. Copeia 1979 (2): 242 - 249.

Graf J. D. 1982. Génétique biochimique, zoogéographie et taxonomie des Arvicolidae (Mammalia, Rodentia). Revue suisse Zool. 89: 749 - 787.

Hartl D. L. 1988. A primer of population genetics, Second Edition. Sinauer Associates, Inc., Sunderland: 1-305.

Jacenko V. N. 1982. Comparative karyology and phylogenesis of the voles (Microtinae, Rodentia). Ph.D. Thesis, AN SSSR, Moskva. [In Russian]

Krapp F. 1982. Microtus nivalis (Martins, 1842) Schneemaus. [In: Handbuch der Säugetiere Europas. J. Niethammer and F. Krapp, eds]. Akademische Verlagsgesellschaft. Wiesbaden 1. Band 2/1: 261 - 283 .

Kratochvíl J. 1981. Chionomys nivalis (Arvicolidae, Rodentia). Acta Sc. Nat. Brno 15: 1-62.

Kryštufek B. 1990. Geographic variation in Microtus nivalis (Martins, 1842) from Austria and Yugoslavia. Bonn. zool. Beitr. 41: 121 - 139.

Kryštufek B. and Kovačić D. 1989. Vertical distribution of the snow vole Microtus nivalis (Martins, 1842) in northwestern Yugoslavia. Z. Säugetierk. 54: $153-156$.

Lanza B. and Azzaroli M. L. 1970. I mammiferi delle Alpi Apuane. Lav. Soc. Biogeogr. Ital., N.S. 1: 677 - 714.

Lewis R. E., Lewis J. H. and Atallah S. I. 1967. A review of Lebanese mammals. Lagomorpha and Rodentia. J. Zool. 153: $45-70$.

Meylan A. and Graf J. D. 1973. Caryotype du campagnol des neiges, Microtus nivalis (Martins) en Europe occidentale (Mammalia, Rodentia). Bull. Soc. Vaudoise Sc. Nat. 71: 441 - 446.

Nadachowski A. 1990. Comments on variation, evolution and phylogeny of Chionomys (Arvicolidae). Int. Symp. Evol. Phyl. Biostr. Arvicolids, IGCP 216, Bio-Events, Geol. Survey, Prague: 353 - 368 .

Nei M. 1978. Estimation of average heterozygosity and genetic distance from a small number of individuals. Genetics 89: 583-590.

Nei M. 1987. Molecular evolutionary genetics. Columbia University Press, New York: $1-512$.

Nevo E., Filippucci M. G. and Beiles A. 1990. Genetic diversity in nature and its ecological predictability: comparisons between subterranean, fossorial and aboveground small mammals. [In: Evolution of subterranean mammals at the organismal and molecular levels. E. Nevo and O. Reig, eds]. Wiley-Liss, New York: $347-366$.

Sage R. D., Contreras J. R., Roig V. G. and Patton J. L. 1986. Genetic variation in the South American burrowing rodents of the genus Ctenomys (Rodentia, Ctenomyidae). Z. Säugetierk. 51: 158-172.

Shmida A. 1977. A quantitative analysis of the tragacanthic vegetation of Mt. Hermon and its relations to environmental factors. Ph.D. Thesis [in Hebrew], Hebrew University of Jerusalem, Jerusalem: $1-325$.

Sokal R. R. and Sneath P. H. A. 1963. Principles of numerical taxonomy. W. H. Freeman, San Francisco: 1 -359 .

Spitzenberger F. 1971. Zur Systematik und Tiergeographie von Microtus (Chionomys) nivalis und Microtus (Chionomys) gud (Microtinae, Mammalia) in S-Anatolien. Z. Säugetierk. 36: 370 - 380.

Swofford D. L. and Selander R. B. 1981. BIOSYS-1: a FORTRAN program for the comprehensive analysis of electrophoretic data in population genetics and systematics. J. Hered. 72: $281-283$.

Tchernov E. and Yom-Tov Y. 1988. Zoogeography of Israel. [In: The Zoogeography of Israel. The Distribution and Abundance at a Zoogeographical Crossroad. Y. Yom-Tov and E. Tchernov, eds]. Dr. W. Junk Publishers, Dordrecht: $1-6$. 
Terzea V. 1972. Remarques sur la morphologie dentaire et de la repartition de Microtus nivalis Martins dans le Pleistocene de Roumanie. Trav. Inst. Speol. Emilie Racovitza, Bucarest 11: 271 - 298.

Thorpe J. P. 1982. The molecular clock hypothesis: biochemical evolution, genetic differentiation, and systematics. Ann. Rev. Ecol. Syst. 13: $139-168$.

Werner Y. L. and Avital I. 1980. The herpetofauna of Mt. Hermon and its altitudinal distribution. Isr. J. Zool. 29: $192-193$.

Wright S. 1943. Isolation by distance. Genetics 28: $114-138$.

Wright S. 1978. Evolution and the genetics of populations. 4. Variability within and among natural populations. The University of Chicago Press, Chicago: $1-580$.

Zima J. and Král B. 1984. Karyotypes of European mammals. II. Acta Sc. Nat. Brno 18: 1 - 62.

Zimmermann E. G., Kilpatrick C. W. and Hartl B. J. 1978. The genetics of speciation in the rodent genus Peromyscus. Evolution 32: $565-579$.

Zimmermann K. 1953. Die Schneemaus. Z. Säugetierk. 18: 163 - 170

Received 14 January 1991, accepted 25 May 1991. 